\title{
Evaluation of interleukin-2 and tumor necrosis factor- $\alpha$ levels in patients with lichen planus
}

\author{
Liken planuslu hastalarda interlökin-2 ve tümör nekrozis faktör-a seviyelerinin \\ değerlendirilmesi
}

\author{
Derya Uçmak, Gökçen Balcı, Mehmet Harman \\ Dicle University, Faculty of Medicine, Department of Dermatology, Diyarbakır, Turkey \\ Geliş Tarihi / Received: 12.12.2010, Kabul Tarihi / Accepted: 02.01.2011
}

\begin{abstract}
Objectives: Lichen planus is an immunologic disease mediated by lymphocytes in which $\mathrm{T}$ lymphocytes target at basal cells. It is believed that TNF- $\alpha$ that is released from $T$ lymphocytes and keratinocytes plays a key role in the starting and progression of lichen planus by inducing apoptosis. MHC Class-I antigens on basal keratinocytes and interleukin-2 (IL-2) and IFN-gamma (Y) that are produced from CD4+ T cells stimulate the apoptosis of keratinocytes in lichen planus. The aim of this study was to measured the IL-2 and TNF- $\alpha$ levels in peripheral blood from patients with Lichen planus.
\end{abstract}

Materials and methods: A total of 26 lichen planus patients (18 females, 8 males) that applied to the dermatology policlinics in Dicle University Hosspital between 2004 and 2006 and a healthy control group were included in the study. Serum IL-2 and TNF-a levels were measured by using Immulate 1000 solid phase and two-site chemiluminescent immunometric assay method. The results of patients and control group were compared.

Results: Level of IL-2 (1172.615 \pm 774.967) and TNF- $\alpha$ $(13.361 \pm 5.638)$ were higher in lichen planus to compared controls. IL-2 and TNF- $\alpha$ levels in the patient group were found to be significantly high statistically compared to health control group, respectively $p=0.004$ and $p<0.001$.

Conclusion: The high levels of IL-2 and TNF- $\alpha$ in lichen planus patients support the role of immunity in the pathogenesis of the disease.

Key words: Lichen planus, IL-2, TNF- $\alpha$

\section{ÖZET}

Amaç: Liken planus $\mathrm{T}$ lenfositlerin bazal hücreleri hedef aldığı lenfosit aracılı immünolojik bir hastalıktır. T lenfositlerinden ve keratinositlerden salınan TNF-a'nın apoptozisi indükleyerek liken planusun başlangıç ve progresyonunda anahtar rolü oynadığı düşünülmektedir. Bazal keratinositlerin üzerindeki MHC Class-I antijenler ve CD4+ T hücrelerinden üretilen IL-2 ve IFN-gamma (y) liken planusta keratinositlerin apoptozisini tetiklemektedir. Bizim çalışmamızın amacı liken planuslu hastaların periferik kanlarındaki İL-2 ve TNF-a seviyelerini saptamaktır.

Gereç ve yöntem: Dicle Üniversitesi Tıp Fakültesi Dermatoloji polikliniğine 2004-2006 yılları arasında başvuran 26 liken planuslu hasta (18 kadın, 8 erkek) ve sağlıklı kontrol grubu çalışmaya alındı. Serum IL-2 ve TNF- $\alpha$ seviyeleri Immulate 1000 solid faz ve two-site chemiluminescent immunometric assay yöntemi kullanılarak ölçüldü. Hasta ve kontrol grubunun sonuçları istatistiksel olarak karşılaştırıldı.

Bulgular: IL-2 $(1172,615 \pm 774,967)$ ve TNF-a $(13.361$ $\pm 5,638$ ) seviyeleri liken planuslu hastalarda kontrollere göre daha yüksek saptandı. Hasta grubunda IL-2 ve TNF- $\alpha$ seviyeleri, sağlıklı kontrollere göre istatistiksel olarak anlamlı derecede yüksek bulundu (sırasıyla $p=0.004$ ve $p<0.001)$.

Sonuç: Liken planuslu hastalarda yüksek olarak bulunan IL-2 ve TNF-a seviyeleri hastalığın patogenezinde immünitenin rolünü desteklemektedir.

Anahtar kelimeler: Liken planus, IL-2, TNF- $\alpha$ 


\section{INTRODUCTION}

Lichen planus is a chronic inflammatory disease in which skin and mucous membranes are affected. It plays an important role in the immunological reaction pathogenesis mediated by the cell stimulated by the antigenic changes in skin and mucous, however its etiology is not yet known exactly1. The major intraepithelial lymphocytes in lichen planus are CD8+ cytotoxic T lymphocytes. TNF- $\alpha$ that is released by these cells and that is found at high levels of serum in active disease plays an important role in apoptosis pathogenesis. ${ }^{1,2}$ In the lesions of lichen planus, subepithelial CD4+ helper T cells were detected in the ratio of $20-40 \%$. The role of $\mathrm{T}$ helper1 cells couldn't be explained completely in the pathogenesis. However, the physiological response to antigen or dysregulation of the immune response may be stimulating the TH1 activity. It is considered that these subepithelial $\mathrm{T}$ cells release pro-inflammatory cytokines such as IFN- $\gamma$ and IL-2 and play role in the pathogenesis of the disease. ${ }^{2}$ Based on this information, we tried to demonstrate the role of immunity in the disease by detecting the serum levels of IL- 2 and TNF- $\alpha$.

\section{MATERIALS AND METHODS}

A total of 26 lichen planus patients (18 females, 8 males) that applied to the dermatology policlinic of Faculty of Medicine of Dicle University between 2004 and 2006 and a healthy control group were included in the study. The patients that had used topical and systemic medicines 3 months prior to the study and the pregnant women and active hepatitis patients were not included in the study. All of the patients were inquired in respect of the age, gender, duration of disease and clinical type of the disease. 26 healthy volunteers were included in the study as control group. Serum IL-2 and TNF- $\alpha$ levels were measured by using Immulate 1000 solid phase and two-site chemiluminescent immunometric assay method. Results were statistically evaluated by student $t$ test.

\section{RESULTS}

The ages of patients varied between 17 and 70 (average 43,65 ) years while they varied between 20 and 70 (average 46.80) in the control group. Statistically, the age distribution with the control group was found to be homogenous. The duration of disease varied between 2 months and 3 years. Serum TNF- $\alpha$ levels in patients were found to be high in 17 of 26 patients while levels of IL-2 were high in 13 of 26 patients (Table 1). When these results are compared with the control group, they were found to be significant $(\mathrm{p}<0.001)$.

Tablo 1. Statistical comparison of patient and control groups

\begin{tabular}{lllll}
\hline & Group & $\mathbf{n}$ & Average & $\mathbf{P}$ \\
\hline Gender & 1 & 26 & $0.692 \pm 0.470$ & 0.265 \\
& 2 & 26 & $0.615 \pm 0.496$ & \\
Age & 1 & 26 & $43.65 \pm 3.40$ & 0.132 \\
& 2 & 26 & $48.3 \pm 10.0$ & \\
Duration & 1 & 26 & $10.0 \pm 14.1$ & 0.001 \\
& 2 & 26 & $0.00 \pm 0.00$ & \\
Type & 1 & 26 & $1.95 \pm 1.26$ & $<0.001$ \\
& 2 & 26 & $0.00 \pm 0.00$ & \\
TNF- $\alpha$ & 1 & 26 & $13.36 \pm 5.64$ & $<0.001$ \\
& 2 & 26 & $7.66 \pm 1.65$ & \\
IL-2 & 1 & 26 & $1172 \pm 775$ & 0.004 \\
& 2 & 26 & $645 \pm 184$ & \\
\hline
\end{tabular}

\section{DISCUSSION}

Lichen planus is a $\mathrm{T}$ cell mediated inflammatory dermatosis. ${ }^{3}$ Degeneration is observed in histopathologically common subepidermal cell infiltrates, numerically increased intraepithelial $\mathrm{T}$ cells and basal cells. Degenerated basal keratinocytes form eosinophilic globules containing colloid or Civatte bodys. ${ }^{4,5}$ The recent studies suggest that auto-reactive $\mathrm{T}$ cells stimulate keratinocytes apoptosis in lichen planus. ${ }^{6}$ Cell mediated immunity in lichen planus is regulated by many cytokines and receptors. In a study conducted by Khan et al.; the cytokines that are released from lesion $\mathrm{T}$ cells were examined in vitro and both pro-inflammatory (INF$\gamma$ IL-2, TNF- $\alpha$ ) and immunosuppressive (TGF-beta) cytokines were detected. It was concluded that these cytokines may be effective in the clinical progress of the disease. ${ }^{2}$

In lichen planus lesions, subepithelial and intraepithelial are major lymphocyte CD8+ cytotoxic 
$\mathrm{T}$ cells. In previous studies, CD8+T lymphocytes were detected in adjacent areas to degenerated basal keratinocytes too. ${ }^{7,8}$ In addition, it was detected that $\mathrm{CD} 8+\mathrm{T}$ cell clones isolated in lichen planus lesions showed cytotoxic activity against autologous keratinocytes in vitro. ${ }^{6,9}$ All this information suggests that CD8+ cytotoxic $\mathrm{T}$ cells play important role in the pathogenesis of the disease and stimulate keratinocytes apoptosis. $^{2}$

Apoptosis is a systematical dying of cells. ${ }^{4,10}$ Apoptotic mechanism is responsible for the basal cell degeneration in lichen planus. ${ }^{5}$ Regulation of apoptosis is relate to the relationship between effector and suppressor molecules. ${ }^{11}$ The probable mechanisms that $\mathrm{T}$ cells stimulate keratinocytes apoptosis might be: (i) linking of TNF- $\alpha$ that is release from $\mathrm{T}$ cells to the TNF- $\alpha$ receptor-1 (TNF R1) on the surface of the keratinocyte; (ii) linkage of Fas receptor (FasR) on the T cell surface to Fas ligand (FasL); or (iii) granzyme $\mathrm{B}$ that is released from $\mathrm{T}$ cells and cause perforations in membrane pores. ${ }^{9}$ In previous studies, serum TNF- $\alpha$ levels were found to be high in lichen planus patients and it was demonstrated that lesional $\mathrm{T}$ cells contained TNF- $\alpha$ m-RNA and released TNF- $\alpha$ in vitro. ${ }^{3,12}$ Based on this information, although it is considered that $\mathrm{CD} 8+$ cytotoxic $\mathrm{T}$ cells release TNF- $\alpha$ and stimulated keratinocyte apoptosis by means of TNF R1, the role of Fas and granzyme $\mathrm{B}$ in the pathogenesis could not be excluded. $^{2}$

In latest studies, CD4+ helper T cells were detected in the ratio of $20-40 \%$ especially in lamina propiada in the subepidermal infiltrate in lichen planus. ${ }^{13}$ In early lichen planus lesions, CD4+ helper T cells are activated as a result that antigen is linked to MHC class II in lichen planus lesions. This is followed by the activation of CD8+ cytotoxic T cells that stimulate keratinocytes apoptosis. Presentation of MHC Class II antigen in lichen planus may be provided by Langerhans cells and keratinocytes. ${ }^{14}$ In lesional skin, MHC class II upregulation and increase in langerhans cells were detected. It stimulates a high level of antigen expression, CD40 and CD80 coexpression and IL-12 secretion from cells presenting antigen and IL- 2 and INF- $\gamma$ secretion from Th1 CD4+T cells. ${ }^{15}$ Subsequently, CD8+ cytotoxic $\mathrm{T}$ cells are activated by both antigens related to MHC class I in basal keratinocytes and also by IL-2 and INF- $\gamma$ that are generated from CD4+T cells. In conclusion, activated $\mathrm{CD} 8+$ cytotoxic $\mathrm{T}$ cells stimulate apoptosis in basal keratinocytes in lichen planus. ${ }^{2}$

In our study, IL-2 and TNF- $\alpha$ levels in the patient group were found to be significantly high statistically compared to health control group. The high levels of IL-2 and TNF- $\alpha$ in lichen planus patients support the role of immunity in the pathogenesis of the disease.

\section{REFERENCES}

1. Carozzo M, Uboldi de Capei M, Dametto et al. Tumor necrosis factor-alpha and interferon-gamma polymorphism contribute to susceptibility to oral lichen planus. J Invest Dermatol 2004; 122(1):87-94.

2. Khan A, Farah CS, Savage NW et al. Oral biology and pathology. J Oral Pathol Med 2003; 32(2):77-83.

3. Sklavounou A, Chrysomali E, Scorilas A, Karameris A. TNF-alpha and apoptosis-regulating proteins in oral lichen planus: a comparative immunohistochemical evaluation. J Oral Pathol Med 2000; 29(8): 370-5.

4. Bascones C, Gonzalez MA, Esparza G, Gil JA, Bascones A. Significance of liquefaction degeneration in oral lichen planus: a study of its relationship with apoptosis and cell cycle arrest markers. Clin Exp Dermatol 2007;32(5):556-63.

5. Kim SG, Chae CH, Cho BO, Kim HN, Kim HJ, Kim IS, Choi JY. Apoptosis of oral epithelial cells in oral lichen planus caused by upregulation of BMP-4. J Oral Pathol Med 2006 J; 35(1):37-45.

6. Sugerman PB, Satterwhite K, Bigby M. Autocytotoxic T-cell clones in lichen planus. Br J Dermatol 2000; 142(3): 44956.

7. Kilpi AM. Activation marker analiysis of mononuclear cell infiltrates of oral lichen planus in situ. Scand J Dent Res 1987; 95(2): 174-80.

8. Jubgell P. Immunoelectron microscopic study of the basement membrane in oral lichen planus. J Cutan Pathol 1990; 17(2): 72-6.

9. Sugerman PB, Savage NW. Oral lichen planus: causes, diagnosis and management. Aust Dent J. 2002; 47(4): 290-7.

10. Cohen JJ. Apopitosis. Immunol Today 1993; 14(3): 126-30.

11. Neppelberg E, Johannessen AC, Jonsson R. Apoptosis in oral lichen planus. Eur J Oral Sci. 2001; 109(5): 361-4.

12. Simark MC, Jobtell M, Bergenholtz G et al. Distribution of interferon- $\gamma$ mRNA-positive cells in oral lichen planus lesions. J Oral Pathol Med 1999; 27(10): 483-8.

13. Ishii $\mathrm{T}$. Immunohistochemical demonstration of $\mathrm{T}$ cell subsets and accessory ceels in oral lichen planus. J Oral Pathol 1987; 16(7): 356-61.

14. Rich AM, Reade PC. A quavtitative assesment of langerhans ceels in oral mucosal lichen planus and leukoplakia. Br J Dermatol 1989; 120(2): 223-8.

15. Constant SL, Bottomly K. Induction of Th 1 and Th 2 CD+ $\mathrm{T}$ cell responses: the alternative approaches. Annu Rev Immunol 1997; 15: 297-322. 